International Research Journal of Management, IT \& Social Sciences
Available online at https://sloap.org/journals/index.php/irjmis/
Vol. 9 No. 2, March 2022, pages: 226-234
ISSN: 2395-7492
https://doi.org/10.21744/irjmis.v9n2.2049

\title{
Effect of Inflation, Consumption Credit on Purchase Power of the Community
}

Article history:

Submitted: 18 November 2021

Revised: 09 December 2021

Accepted: 27 January 2022

\section{Keywords:}

consumption credit; economic growth; income per capita; inflation;

purchase power;

\begin{abstract}
The people's purchasing power as seen through per capita expenditure adjusted for the province of West Java during the last 4 years 2017-2020, tends to increase and in the last year the purchasing power of the people of West Java has decreased due to the influence of the COVID-19 pandemic. The purpose of this study is to analyze the effect of inflation and consumption credit on people's purchasing power in the province of West Java. The results of the study show that inflation and the distribution of banking consumption credit simultaneously have a significant effect on people's purchasing power. Partially, inflation has a negative and significant effect on people's purchasing power, while banking consumption credit has a positive and significant impact on people's purchasing power, economic growth, income per capita and other unknown variables.
\end{abstract}

International research journal of management, IT and social sciences (C) 2022. This is an open access article under the CC BY-NC-ND license (https://creativecommons.org/licenses/by-nc-nd/4.0/).

Corresponding author:

Hartanto Halim,

Borobudur University, Jakarta, Indonesia.

Email address: hartantohalim35@gmail.com

\footnotetext{
Borobudur University, Jakarta, Indonesia

Borobudur University, Jakarta, Indonesia Borobudur University, Jakarta, Indonesia 


\section{Introduction}

Economic development is inseparable from the parameters of success for the welfare of its people, among others through the provision of jobs (Alam et al., 2013). Reducing the goal of increasing people's purchasing power, increasing per capita income continuously and producing in the long term. West Java, one of the provinces in Indonesia which has 27 (twenty seven) districts and cities at the level of two, consists of 18 (eighteen) districts and 9 (nine) municipal areas (Baltagi, 1995). Development in the province of West Java continues to process and is growing along with the increasing purchasing power of the people as measured by per capita spending of the population adjusted for PPP (purchasing power parity). Population per capita expenditure is the cost incurred for the consumption of all household members for a month divided by the number of household members (Bungin, 2013).

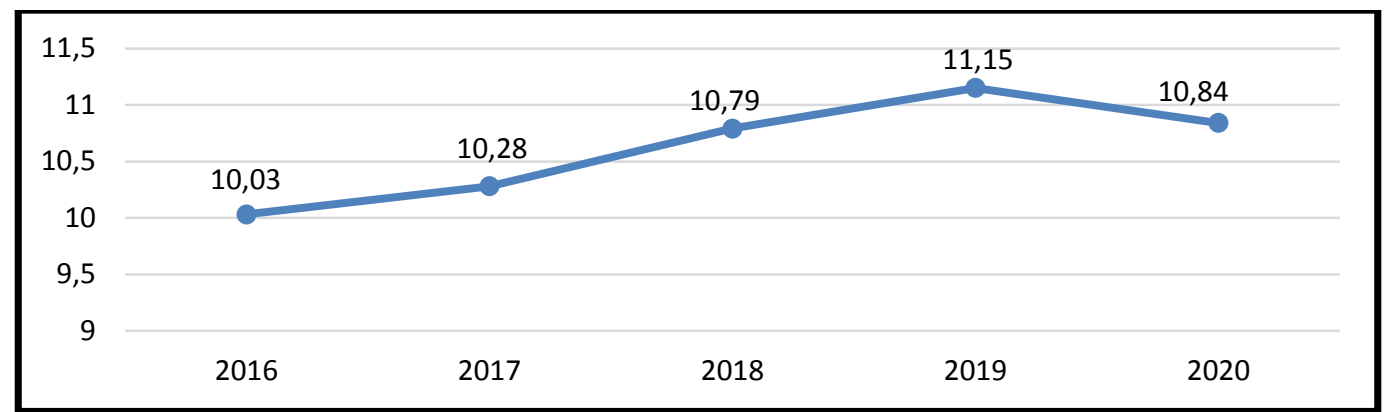

Figure 1. Above PPP Adjusted Expenditures per Capita West Java Province 2016 - 2020 (Million Rupiah) Source: BPS West Java Province, processed

In Figure 1 above the purchasing power of the people of West Java as seen through the PPP-adjusted average level of per capita expenditure in West Java province from 2016-2019 continues to increase. In 2017 the average expenditure per capita was Rp. 10.28 million, which was higher than the average expenditure per capita in 2016 of Rp. 10.03 million (Del Giudice et al., 2020; Gil-Alana \& Yaya, 2021). In 2018 the average per capita expenditure of IDR 10.79 million increased compared to 2017 and the 2019 average per capita expenditure of IDR 11.15 million also experienced an increase compared to the average per capita expenditure in 2018. However, the average expenditure per capita population of West Java province in 2020 amounted to Rp. 10.84 million, nominally decreased by 2.75 percent compared to 2019 which was Rp. 11,152 million per capita a year (Ruiz Estrada, 2021). This indicates that the welfare level of the population of West Java province during the COVID-19 pandemic has decreased in terms of purchasing power as measured by PPP-adjusted spending per capita of the population.

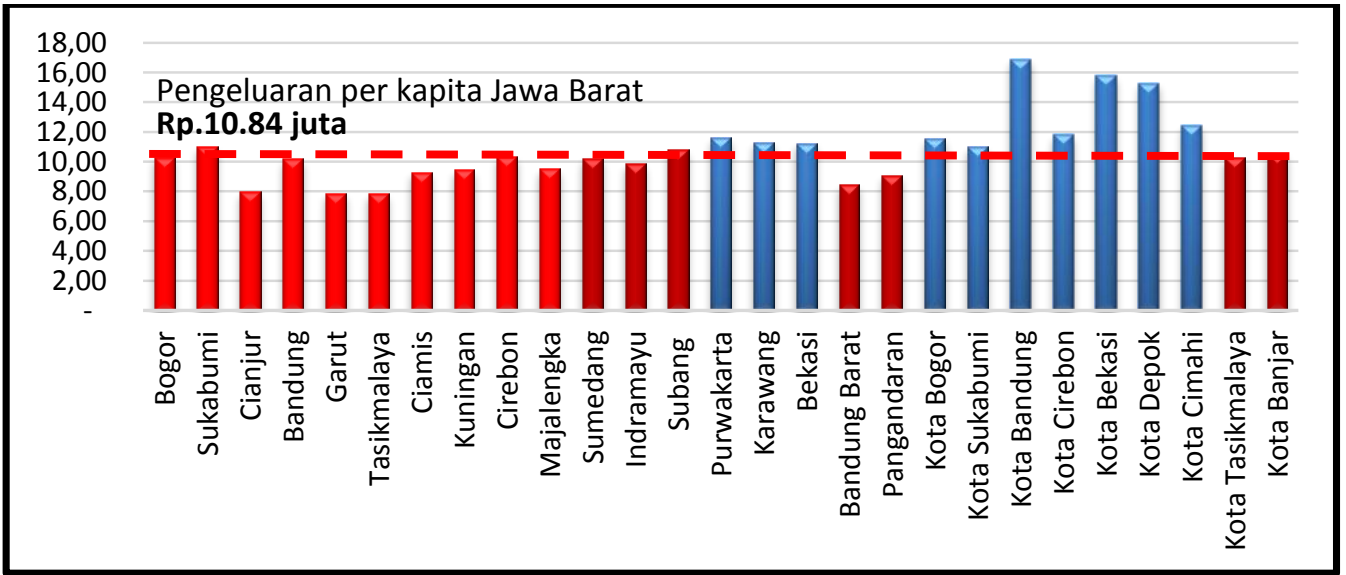

Figure 2. Above Expenditures per Capita Adjusted by Regency/City PPP in West Java Province in 2020 (Million Rupiah)

Source: BPS West Java Province 2020, processed

Halim, H., Astuty, P., \& Hubeis, M. (2022). Effect of inflation, consumption credit on purchase power of the community. International Research Journal of Management, IT and Social Sciences, 9(2), 226-234. https://doi.org/10.21744/irjmis.v9n2.2049 
From the picture above, it can be seen that in 2020 there are 10 (ten) districts/cities with PPP levels above West Java, namely Purwakarta district of Rp. 11.61 million, Karawang district of Rp. 11.31 million, Bekasi district of Rp. 11.24 million, Bogor city of Rp. 11.56 million, Sukabumi city of Rp. 11.00 million, Bandung city of Rp. 16.89 million, Cirebon city of Rp. 11.80 million, Bekasi city of Rp. 15.78 million, Depok city 15.28 million, and Cimahi city 12.02 million and the remaining 17 (seventeen) districts/cities with PPP level below West Java (Bacchetta \& Gerlach, 1997; Attanasio, 1999). So it can be said that in the province of West Java, there are still disparities between districts/cities in terms of per capita expenditure adjusted for PPP (Zain, 2009). There are several factors that affect people's purchasing power. One of the factors that can affect people's purchasing power is inflation (Prasetyo \& Firdaus, 2009).

Inflation is a tendency to increase the price of goods and services in general, which takes place continuously. If the price of goods and services in the country increases, then inflation will increase. The increase in the price of goods and services causes a decrease in the value of money (Acemoglu, 2012; Arrow et al., 1995). Thus, inflation can also be interpreted as a decrease in the value of money against the value of goods and services in general. Inflation plays an important role in determining economic conditions. Inflation directly or indirectly affects the economy, if people perceive high inflation it will affect the economy as a whole. "Inflation as a condition in which the general price level increases" (Kuncoro, 2015). The purpose of this definition indicates a weakening of people's purchasing power followed by a decrease in the real (intrinsic) value of a country's currency (Monadjemi \& Lodewijks, 2021; Nanga, 2005; Pamungkas, 2018).

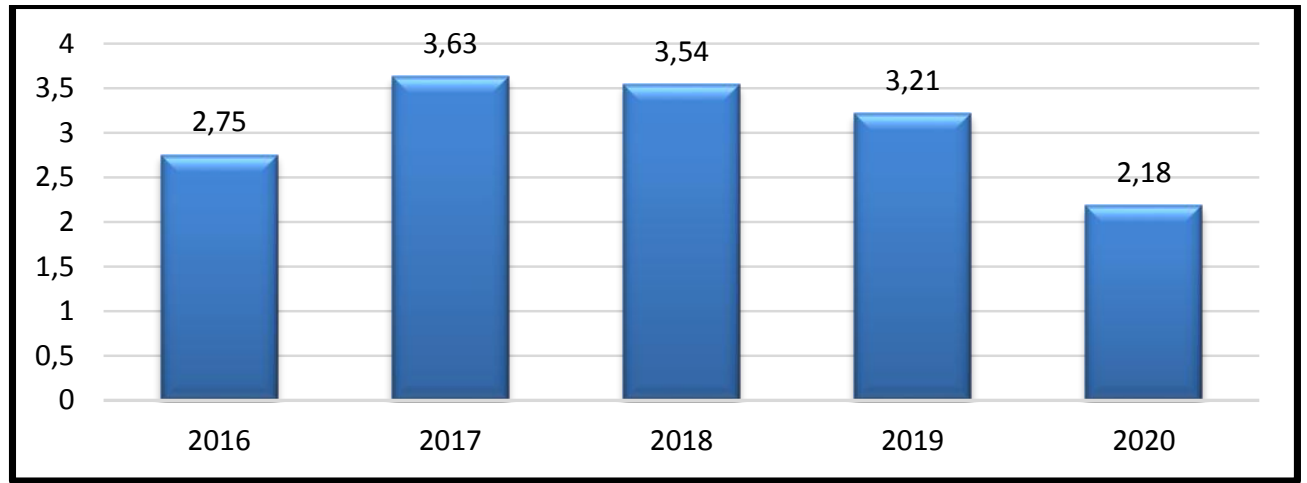

Figure 3. General the combined inflation of 7 (seven) cities in West Java during 2020 Source: BPS West Java Province, processed

Based on the picture above, in general the combined inflation of 7 (seven) cities in West Java during 2020 was 2.18 percent. In 2019, the combined inflation of 7 (seven) cities reached 3.21 percent. During the last five years, inflation in 2020 was the lowest annual inflation (Haji-Othman \& Yahaya, 2015; Niu et al., 2016). The highest inflation occurred in 2017 at 3.63 percent (Boediono, 2016). West Java inflation in 2020 is still within the target range of 3 percent \pm 1 percent, in line with the still limited economic improvement. This is due to the limited purchasing power of the public which has resulted in decreased demand and restrictions on business activities in line with government policies to prevent the spread of the COVID-19 pandemic (Jeke \& Wanjuu, 2021; Mankiw, 2010).

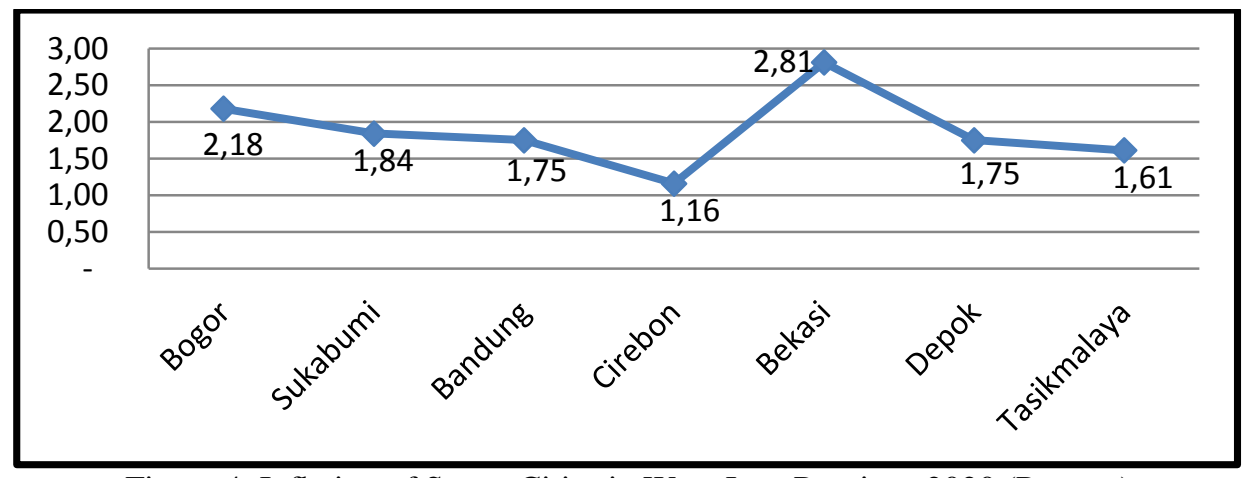

Figure 4. Inflation of Seven Cities in West Java Province 2020 (Percent)

Source: BPS West Java Province 2020, processed 
Based on Figure 4 above, the combined inflation of 7 cities in West Java in 2020 reached 2.18 percent (yoy). Bekasi City is the area that has the highest inflation rate in West Java in 2020, which is 2.81 percent. Followed by the city of Bogor by 2.18 percent. In these two regions, inflation achievement is higher than the average for West Java, while the other five cities are lower than West Java (Greer \& Thorbecke, 1986). Cirebon City is the area with the lowest inflation in West Java at 1.16 percent. Sukabumi City, Bandung City, and Depok City along with Tasikmalaya City are the areas where inflation achievement is below 2 percent. The two cities with the highest inflation in West Java have similar characteristics, namely acting as a consumer area and not a producer area. This causes the two regions to have a high dependence on areas that supply consumption materials. Thus, inflationary pressures in these two regions are highly dependent on distribution patterns. On the other hand, the two cities are also very close to the capital city of Jakarta so that the inflation pattern tends to be more influenced by Jakarta's inflation movements (Alvarado et al., 2018; Markusen, 2013).

In general, the challenges or obstacles to controlling inflation in West Java stem from weather factors, annual events such as religious holidays, and the lack of information on food balance data and food distribution networks so that the distribution of food commodities is not optimal (Mansur, 2019; Sedyaningrum et al., 2016). This can be seen from most of the commodities that contributed to the largest inflation in West Java, namely food commodities produced by several regions in West Java (Wulandari1 et al., 2019). However, because the distribution is not optimal and the food commodity surplus/deficit data is incomplete, food commodities from producing areas in West Java are not distributed to consumer areas in other provinces, such as DKI Jakarta and Banten. This causes consumer areas in West Java to have to meet food needs from other provinces at higher prices (considering the long distances and high transportation costs) (Lane, 1997; Al-Marhubi, 2000).

Another factor that can increase purchasing power is consumer credit. Consumer credit is one of the services provided by banks in the form of credit aimed at financing customer needs, especially those related to consumption activities (Jhingan, 2012). Consumption credit is used for personal consumption or use. In this credit, there is no increase in the goods and services produced, because they are intended to be used or used by a person or business entity (Yeo, 2015). The theory put forward by Habad Muliaman et al. (2004), also states that "one of the factors driving the development of consumption is credit for consumption purposes which tends to increase in the same period, consumption credit in general is household credit".

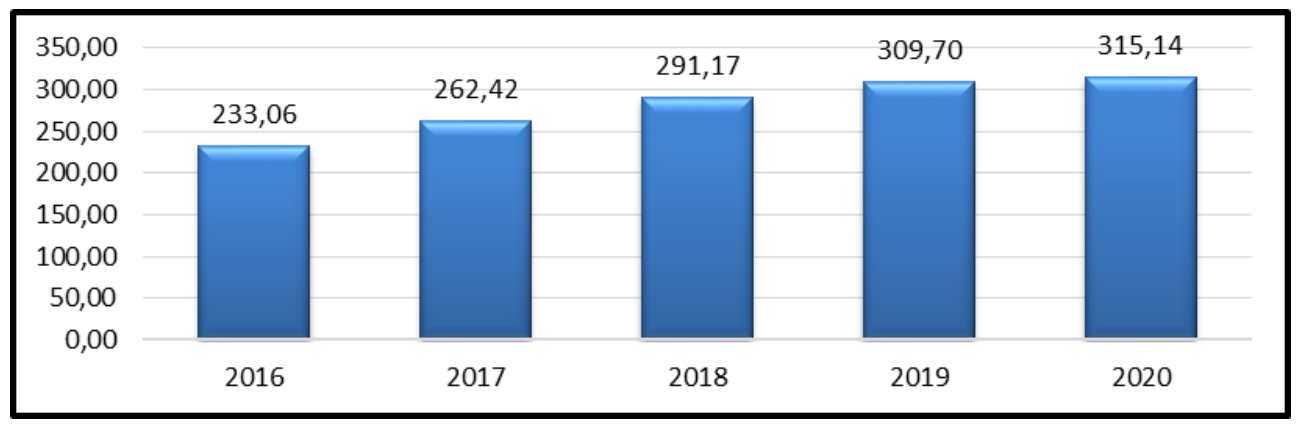

Figure 5. Distribution of Consumption Loans Provided by Banks in West Java Province Year 2016-2020 (Billion Rupiah).

Source: BPS West Java Province, processed

Based on Figure 5 above consumer credit distribution provided by banks in West Java province from 2016-2020 continues to increase (Bahsan, 2007). In 2020, the distribution of consumer loans amounted to Rp. 315.14 trillion, an increase compared to 2019 of Rp. 309.70 trillion or an increase of 1.75 percent. In 2020, during the COVID-19 pandemic, people tend to hold back on consumption by reducing tertiary spending due to a decline in income, so demand for consumption credit is still limited. Based on this background, the researcher raised the problem of people's purchasing power in the province of West Java as the central theme of this study with the title "The Effect of Inflation, consumption credit on people's purchasing power in the province of West Java" (Gujarati, 2006). The reason and consideration for choosing the title is because the economic development of West Java province is growing rapidly, one of which is the increase in people's purchasing power. The increase in people's purchasing power will have an impact on increasing the economy in the province of West Java so that the unemployment and poverty rate in this

Halim, H., Astuty, P., \& Hubeis, M. (2022). Effect of inflation, consumption credit on purchase power of the community. International Research Journal of Management, IT and Social Sciences, 9(2), 226-234. 
province will decrease significantly so that the welfare of the community will increase (Flurry \& Burns, 2005; Bruck et al., 2018).

\section{Methods}

\section{Data types and sources}

In this study the data used is quantitative data is data in the form of numbers and can be measured. The data used in this study is secondary data, namely data in the form of annual reports that have been prepared and published by related parties (Sugiyono, 2017). The data needed in this study is secondary data whose collection is in the form of cross section data of 27 (twenty seven) districts/cities and time series data for 3 (three) years, from 2017 to 2020 . The research was carried out for 1 year, from January 2021 to December 2021, starting from the process of determining the research title, preparing proposals, research area permits, determining the units to be analyzed, collecting data and facts in the field to processing and analyzing data (Moleong, 2018). The place or object of research data is carried out in the province of West Java by analyzing secondary data in several districts and cities such as Bogor district, Sukabumi district, Cianjur district, Bandung district, Garut district, Tasikmalaya district, Ciamis district, Kuningan district, Cirebon district, district Majalengka, Sumedang district, Indramayu district, Subang district, Purwakarta district, Karawang district, Bekasi district, West Bandung district, Pangandaran district, Bogor city, Sukabumi city, Bandung city, Cirebon city, Bekasi city, Depok city, Cimahi city, Tasikmalaya city, and the city of Banjar which is the research location (Sutarjo et al., 2021; Sholahuddin et al., 2021).

\section{Population, sample and sampling}

In this study, what is meant by population is all data on research variables since the formation of West Java Province until 2020 which relates to all variables to be studied (Riani et al., 2018). While the sample used in this study is research variable data from 2017 to 2020 using panel data related to economic growth, per capita income, inflation, consumption credit, unemployment rate and poverty rate in West Java province in 27 (seven) district/city.

\section{Panel data regression model selection}

According to Basuki \& Prawoto (2016), in the selection of model parameters with panel data, there are three panel regression approaches that will be used, namely the ordinary least square (OLS) or common effect model, the fixed effect method, and the fixed effect method. Random effect (random effect model). Selection of Panel Data Regression Model ' Panel data regression analysis using eviews was carried out using a three-model approach, (Hidayati \& Maskuri, 2020). Namely the Common Effect Model (CEM), Fixed Effect Model FEM, and Random Effect Model (REM):

1. The Chow test is a test by comparing the common effect regression model (CEM) with the fixed effect model (FEM) regression model.

2. Hausman test, which is a test by comparing the fixed effect regression model with the random effect regression model.

3. Lagrange Multiplier test, which is a test by comparing the common effect regression model with the random effect regression model. Of the three regression models, after testing the model, the best regression model can be obtained, then the researcher conducts further tests with the classical assumption test.

4. The selection between the common effect, fixed effect and random effect methods is carried out in 2 stages, namely: (a). Selection between common effect and fixed effect method (Chow test) (b). Hausman test (Hausman test: used to determine the suitable method between the fixed effect and random effect model. 


\section{Results and Discussions}

After three tests were carried out, namely the Cammon Effect Model Test, Fix Effect Model, Random Effect Model with the Chow test stage and the Hausman test, the best test results fell on the Random Effect Model (REM) method with the Hausman test stage to determine the appropriate method. Between fixed effect and random effect models.

\section{Hausman test stage}

The table below shows the probability value of $0.5314>0.005$ which means that the selection of the three tests falls on the Random Effect Model (REM) model.

Table 1

Probability value

\begin{tabular}{rccc}
\hline Test Summary & Chi-Sq. Statistic & Chi-Sq. d.f. & Prob. \\
\hline Cross-section random & 1.264542 & 2 & 0.5314 \\
\hline
\end{tabular}

Test random effect model

Table 2

Test random effect model

\begin{tabular}{llccc}
\hline \multicolumn{1}{c}{ Variable } & \multicolumn{1}{c}{ Coefficient } & Std. Error & t-Statistic & Prob. \\
\hline INFLATION & -175874.5 & 29499.05 & -5.962040 & 0.0000 \\
CONSUMPTION CREDIT & 120.8407 & 19.07181 & 6.336086 & 0.0000 \\
C & 9760356. & 440204.7 & 22.17231 & 0.0000 \\
& Effects Specification & & S.D. & Rho \\
Cross-section random & & & 1883262. & 0.9811 \\
Idiosyncratic random & & & 261160.4 & 0.0189 \\
& & & 732822.3 \\
R-squared & Weighted Statistics & & 367266.5 \\
Adjusted R-squared & 0.507275 & Mean dependent var & $7.11 \mathrm{E}+12$ \\
S.E. of regression & 0.497890 & S.D. dependent var & 1.900157 \\
F-statistic & 260244.1 & Sum squared resid & \\
Prob(F-statistic) & 54.05027 & Durbin-Watson stat & \\
\multicolumn{2}{c}{} & & 10594333 \\
R-squared & 0.000000 & Unweighted Statistics & & 0.037016 \\
Sum squared resid & 0.327871 & Mean dependent var & \\
\hline
\end{tabular}

\section{Random effect model panel data regression for model 1}

The interpretation of the panel data regression test results using the Random effect method, through multiple linear regression of panel data which shows a causal relationship between the independent variables and the dependent variable as follows:

Equation Model 1:

$$
\mathrm{Ln} \_\mathrm{Y}=\mathrm{o}+1 \mathrm{Ln} \_\mathrm{X} 1+2 \mathrm{Ln} \_\mathrm{X} 2+\mathrm{e}
$$

Where:

$$
\begin{array}{ll}
\text { Ln_Y } & =\text { People's Purchasing Power } \\
\text { o } & =\text { Constant } \\
\text { Ln_X1 } & =\text { Inflation }
\end{array}
$$

Halim, H., Astuty, P., \& Hubeis, M. (2022). Effect of inflation, consumption credit on purchase power of the community. International Research Journal of Management, IT and Social Sciences, 9(2), 226-234. 
Ln_X2 = Consumer Credit

$1 \ldots 5=$ Regression Coefficient of each independent variable

$1=$ Epsillon

The results of the calculations in the table above can be presented with the results of multiple linear regression of panel data as follows: Purchasing Power $=9760356-175874.5 \mathrm{X} 1+120.8407 \mathrm{X} 2+\mathrm{e}$

\section{Hypothesis testing}

From the results of the Random Effect Model Test table above, it can be concluded as follows:

1. Simultaneously, the variables of Inflation, Consumption Credit have a positive and significant effect on the People's Purchasing Power variable.

2. Partially the inflation variable has a negative and significant effect on the community's purchasing power variable.

3. Partially, the variable consumption credit has a positive and significant effect on the public purchasing power variable.

\section{Conclusion}

1. Simultaneously, the variables of Inflation, Consumption Credit have a positive and significant effect on the People's Purchasing Power variable.

2. Partially the inflation variable has a negative and significant effect on the community's purchasing power variable, meaning that when inflation occurs in the community in the province of southwest Java, the community's purchasing power decreases.

3. Partially, the variable consumption credit has a positive and significant effect on the community purchasing power variable in the province of west java, meaning that when purchasing goods on credit, the purchasing power of the community also increases.

\section{Suggestion}

1. To increase people's purchasing power during the COVID-19 pandemic, the provincial government must be able to encourage an increase from the demand side through the realization of social assistance, one of which is in the form of basic necessities and cash assistance to help the poor and vulnerable to be able to reach their needs. basic services such as food, education and health in order to avoid various risks of social decline.

2. To control inflation so that it remains stable, the West Java provincial government and Bank Indonesia need to implement strategic steps, namely by maintaining volatile food inflation in the range of $4.0 \pm 1$ percent by strengthening four strategic pillars which include price affordability, supply availability, smooth distribution, and effective communication (4K). The implementation of this strategy is focused on reducing price disparities between time and between regions. The synergy of policies adopted by the West Java provincial government and Bank Indonesia is expected to keep inflation under control within the target range of $3.0 \pm 1$ percent.

\section{Conflict of interest statement}

The authors declared that they have no competing interests.

Statement of authorship

The authors have a responsibility for the conception and design of the study. The authors have approved the final article.

\section{Acknowledgments}

We are grateful to two anonymous reviewers for their valuable comments on the earlier version of this paper. 


\section{References}

Acemoglu, D. (2012). Introduction to economic growth. Journal of economic theory, 147(2), 545-550. https://doi.org/10.1016/j.jet.2012.01.023

Alam, K., Tanner, T., Shamsuddoha, M., Rashid, A. K. M., Sultana, M., Huq, M. J., ... \& Ullah, S. (2013). Planning "exceptionalism"? Political economy of climate resilient development in Bangladesh. In Climate change adaptation actions in Bangladesh (pp. 387-417). Springer, Tokyo.

Al-Marhubi, F. A. (2000). Corruption and inflation. Economics Letters, 66(2), 199-202. https://doi.org/10.1016/S01651765(99)00230-X

Alvarado, R., Ponce, P., Criollo, A., Córdova, K., \& Khan, M. K. (2018). Environmental degradation and real per capita output: new evidence at the global level grouping countries by income levels. Journal of Cleaner Production, 189, 13-20. https://doi.org/10.1016/j.jclepro.2018.04.064

Arrow, K., Bolin, B., Costanza, R., Dasgupta, P., Folke, C., Holling, C. S., ... \& Pimentel, D. (1995). Economic growth, carrying capacity, and the environment. Ecological economics, 15(2), 91-95. https://doi.org/10.1016/09218009(95)00059-3

Attanasio, O. P. (1999). Consumption. Handbook of macroeconomics, 1, 741-812. https://doi.org/10.1016/S15740048(99)10019-3

Bacchetta, P., \& Gerlach, S. (1997). Consumption and credit constraints: International evidence. Journal of Monetary Economics, 40(2), 207-238. https://doi.org/10.1016/S0304-3932(97)00042-1

Bahsan, M. (2007). Indonesian Banking Credit Guarantee and Guarantee Law. Jakarta: PT.

Baltagi, B. H. (1995). Econometric analysis of panel data (Vol. 2). New York: Wiley.

Basuki, A. T., \& Prawoto, N. (2016). Analisis Regresi dalam Penelitian Ekonomi dan Bisnis.

Boediono. (2016). Macro economics. Yogyakarta: BPFE

Bruck, M., Sandborn, P., \& Goudarzi, N. (2018). A Levelized Cost of Energy (LCOE) model for wind farms that include Power Purchase Agreements (PPAs). Renewable Energy, 122, 131-139. https://doi.org/10.1016/j.renene.2017.12.100

Bungin, B. (2013). Social \& Economic Research Methodology: Quantitative and Qualitative Formats for Sociology. Public Policy, Communication, Management, and Marketing Studies. Jakarta: Golden.

Del Giudice, V., De Paola, P., \& Del Giudice, F. P. (2020). COVID-19 infects real estate markets: Short and mid-run effects on housing prices in Campania region (Italy). Social sciences, 9(7), 114.

Flurry, L. A., \& Burns, A. C. (2005). Children's influence in purchase decisions: a social power theory approach. Journal of Business Research, 58(5), 593-601. https://doi.org/10.1016/j.jbusres.2003.08.007

Gil-Alana, L. A., \& Yaya, O. S. (2021). Testing fractional unit roots with non-linear smooth break approximations using Fourier functions. Journal of Applied Statistics, 48(13-15), 2542-2559.

Greer, J., \& Thorbecke, E. (1986). A methodology for measuring food poverty applied to Kenya. Journal of Development Economics, 24(1), 59-74.

Gujarati, D. (2006). Fundamentals of Econometrics. Penerbit Erlangga, Jakarta.

Hadad Muliaman, D., Wimboh, S., \& Sarwedi, M. P. K. B. (2004). UMUM DI INDONESIA. Direktorat Penelitian dan Pengaturan Perbankan.

Haji-Othman, Y., \& Yahaya, S. (2015). Purchasing power parity: evidence from selected high and low inflation countries. International Business Research, 8(1), 50.

Hidayati, N., \& Maskuri, M. A. (2020). Inflasi, Tingkat Pengangguran Dan Daya Beli Masyarakat Di Kabupaten Bogor. Jurnal Manajemen Kewirausahaan, 17(2), 137-142.

Jeke, L., \& Wanjuu, L. Z. (2021). The economic impact of unemployment and inflation on output growth in South Africa. Journal of Economics and International Finance, 13(3), 117-126.

Jhingan, M. L. (2012). The economics of development and planning 40th edition.

Kuncoro, M. (2015, October). Economic Geography of Indonesia’s Manufacturing Industry: Dynamics and Changing Spatial Patterns. In Seminar Nasional \& Kongres ISEI XIX”; Hotel Bumi Surabaya (pp. 19-23).

Lane, P. R. (1997). Inflation in open economies. Journal of International Economics, 42(3-4), 327-347. https://doi.org/10.1016/S0022-1996(96)01442-0

Mankiw, N. G. (2010). Intermediate macroeconomics.

Mansur, A. (2019). Sharia banking dynamics and the macroeconomic responses: Evidence from Indonesia.

Markusen, J. R. (2013). Putting per-capita income back into trade theory. Journal of International Economics, 90(2), 255-265. https://doi.org/10.1016/j.jinteco.2013.04.003

Halim, H., Astuty, P., \& Hubeis, M. (2022). Effect of inflation, consumption credit on purchase power of the community. International Research Journal of Management, IT and Social Sciences, 9(2), 226-234.

https://doi.org/10.21744/irjmis.v9n2.2049 
Moleong, L. J. (2018). Metode penelitian kualitatif, cetakan ke-37. Bandung: PT. Remaja Rosdakarya.

Monadjemi, M., \& Lodewijks, J. (2021). International Evidence on Purchasing Power Parity: A Study of High and Low Inflation Countries. Journal of Economics and Management Sciences, 4(3), p1-p1.

Nanga, M. (2005). Makro Ekonomi: Teori, Masalah, dan Kebijakan, Jakarta: PT. Grafindo Persada.Muhammad Abdul Halim., (2012). Theory of Economics Edition 1, Tangerang: Explore Nusa.

Niu, H., Chu, X., \& Ma, Y. (2016). Study on the Fluctuation of Purchasing Power Parity. Open Journal of Business and Management, 4(01), 67.

Pamungkas, P. A. (2018). The Impact Of Unemployment Rate, Labor Force, Capital, Inflation Rate, And Government Expenditure On Economic Growth In Indonesia. American Journal of Engineering Research, 7(3), $109-119$.

Prasetyo, R. B., \& Firdaus, M. (2009). Pengaruh infrastruktur pada pertumbuhan ekonomi wilayah di Indonesia. Jurnal Ekonomi dan Kebijakan Pembangunan, 2(2), 222-236.

Riani, D. D., Octavianus, R. J. N., \& Hutapea, T. M. H. (2018). Analysis of Effect of Exchange Rate, Inflation, and Power Purchase on Distribution of Credit in Common Conventional Banks. Jurnal Aplikasi Manajemen, 16(2), 363-369.

Ruiz Estrada, M. A. (2021). How COVID-19 Quarantine (s) Can Generate Poverty?(preprint).

Sedyaningrum, M., Suhadak, S., \& Nuzula, N. F. (2016). Pengaruh Jumlah Nilai Ekspor, Impor Dan Pertumbuhan Ekonomi Terhadap Nilai Tukar Dan Daya Beli Masyarakat Di Indonesia Studi Pada Bank Indonesia Periode Tahun 2006: iv-2015: iii (Doctoral dissertation, Brawijaya University).

Sholahuddin, M., Manullang, S. O., \& Sari, D. (2021). Understanding review of economic loss due to government policy respond to the COVID-19 disruption in Indonesia. International Journal of Business, Economics \& Management, 4(1), 180-188. https://doi.org/10.31295/ijbem.v4n1.1479

Sugiyono, D. Q. (2017). Qualitative Research Methods. Bandung: Alfabeta.

Sutarjo, S., Murti, W., \& Saleh, S. (2021). The effect of export import, inflation, interest rates, and exchange rates against Indonesia's economic growth. International Journal of Business, Economics \& Management, 4(2), 449460. https://doi.org/10.31295/ijbem.v4n2.1740

Wulandari, D., Utomo, S. H., Narmaditya, B. S., \& Kamaludin, M. (2019). Nexus between inflation and unemployment: Evidence from Indonesia. The Journal of Asian Finance, Economics and Business, 6(2), 269-275.

Yeo, J. (2015). Financial statement analysis.

Zain, M. M. (2009). Elasticity of labour demand and real wages rigidity by sector in South Sulawesi Province. Jurnal Agro Ekonomi. 